\title{
HUBUNGAN PEMBERIAN ASI DENGAN KEJADIAN IKTERUS BAYI HIPERBILIRUBINEMIA DI RSIA PURI BUNDA DENPASAR
}

\author{
Nyoman Sulendri ${ }^{1}$, Komang Yogi Triana ${ }^{2}$, Desak Putu Risna Dewi ${ }^{3}$, \\ Sutresna $^{4}$ \\ ${ }^{1,2,3,4}$ Sekolah Tinggi Ilmu Kesehatan Bina Usada, Bali \\ Email: sulendri1978@gmail.com
}

\begin{abstract}
Early exclusive breastfeeding has an important role in reducing the incidence of jaundice, where jaundice is a change in the skin or other organs due to a buildup of bilirubin levels in the blood and an increase in the level of bilirubin in the blood, which is called hyperbilirubinemia. This study aimed to determine the correlation between breastfeeding and the incidence of hyperbilirubinemia infant jaundice at RSIA Puri Bunda Denpasar. This study used a case-control method, comparing the case group with the control group and a retrospective approach. The number of samples was 86 patients' medical record files. The sampling was using purposive sampling through the observation sheet and data analysis using the Chi-Square test. This study showed that exclusive breastfeeding had less incidence of jaundice $116.7 \%$ in the case and control groups) while the incidence of jaundice was higher in breastfeeding and formula milk in both the case and control groups. The results of the chi-square statistical test obtained pvalue $=0.023$, meaning that there was a significant correlation between breastfeeding and the incidence of jaundice in hyperbilirubinemia infants. It is recommended that the hospital be able to educate and socialize early exclusive breastfeeding to patients.
\end{abstract}

Keywords: exclusive breastfeeding, jaundice, hyperbilirubinemia

\section{PENDAHULUAN}

\section{Angka Kematian Bayi (AKB)} merupakan indikator untuk menentukan derajat kesehatan masyarakat. AKB merujuk kepada jumlah bayi yang meninggal pada fase antara kelahiran hingga bayi belum mencapai umur 1 tahun per 1.000 kelahiran hidup. Masalah utama penyebab kematian pada bayi dan balita adalah pada masa neonatus (bayi baru lahir umur 0-28 hari). Kebanyakan bayi baru lahir mengalami ikterus pada minggu pertama kehidupannya. Data epidemiologi menunjukkan bahwa lebih dari 50\% bayi baru lahir menderita ikterus yang dapat dideteksi secara klinis dalam minggu pertama kehidupannya (Badan Pusat Statistik, 2021).

Menurut WHO (2019) sebanyak 7000 Bayi baru lahir di dunia meninggal setiap harinya (Indonesia: 185/hari, dg AKN 15/1000 Kelahiran hidup), tiga perempat kematian neonatal terjadi pada minggu pertama terjadi pada umur 0-6 hari, dan 40 meninggal dalam 24 jam pertama. Hasil Survei Demografi dan Kesehatan Indonesia (SDKI) tahun 2017 menunjukkan Angka Kematian Neonatal (AKN) sebesar 15 per 1.000 kelahiran hidup atau sekitar 47\%, sedangkan salah satu penyebabnya adalah gangguan 
hematologi sebanyak 6\%. Kematian neonatus yang disebabkan karena masalah hematologi adalah ikterus dan defisiensi vitamin $\mathrm{K}$ (KemenkesRI, 2017).

Seluruh kematian bayi di Indonesia, sebanyak $57 \%$ meninggal pada masa bayi baru lahir (usia dibawah 1 bulan). Angka Kematian Bayi (AKB) di Provinsi DKI Jakarta menurut data Kesga Dinkes DKI Jakarta tahun 2014 sebesar 6,88 per 1.000 kelahiran hidup (KemenkesRI, 2015). AKB di Bali sebesar 6,01 per 1000 kelahiran hidup, di Denpasar AKB sebesar 1,0 per 1000 kelahiran hidup (Dinas Kesehatan, 2017). Menurut profil kesehatan Indonesia tahun 2007 insiden hiperbilirubin berkisar $10 \%-13 \%$, sedangkan angka kejadian Hiperbilirubin di DKI berdasarkan data registrasi Neonatologi bulan Desember 2014 sampai November 2015 di antara 1093 kasus neonatus yang dirawat, didapatkan 165 (15,09\%) kasus dengan ikterus neonatorum (KemenkesRI, 2015). Dari 899 bayi yang masuk keruang Intensif di RSIA Puri Bunda Denpasar, tahun 2019 terdapat 489 bayi dengan kasus Hiperbilirubinemia atau sekitar 55.5\% di Ruang Intensif RSIA Puri Bunda Denpasar, diketahui bahwa kasus bayi dengan hiperbilirubinemia termasuk urutan1 terbesar dan terbanyak dijumpai. Hiperbilirubinemia ini menduduki urutan pertama selanjutnya RDS (respiratory distress syndrome) dan asfiksia, BBLR (Bayi Berat Lahir Rendah).

Ikterus merupakan kondisi munculnya warna kuning di kulit dan selaput mata pada bayi baru lahir karena adanya bilirubin (pigmen empedu) pada kulit dan selaput mata sebagai akibat peningkatan kadar bilirubin dalam darah (hiperbilirubinemia) (Sukadi, 2008). Ikterus pada bayi baru lahir pada minggu pertama terjadi pada $60 \%$ bayi cukup bulan dan $80 \%$ bayi kurang bulan. Hal ini adalah keadaan yang fisiologis. Walaupun demikian, sebagian bayi akan mengalami ikterus yang berat sehingga memerlukan pemeriksaan dan tata laksana yang benar untuk mencegah kesakitan dan kematian (Sukadi, 2008).

Hiperbilirubinemia merupakan peningkatan kadar bilirubin pada ikterus neonatorum setelah adanya hasil laboratorium mencapai suatu nilai yang mempunyai potensi menimbulkan ikterus dan jika tidak ditanggulangi dengan baik akan menyebabkan keterbelakangan mental (Rana, 2018). Kelahiran dengan usia kehamilan 37 minggu hiperbilirubin terjadi apabila bilirubin serum sebesar 12,5 mg/dL. Hiperbilirubin bisa disebabkan proses fisiologis dan patologis.

Ikterus neonatus merupakan penyakit kuning pada bayi yang disebabkan oleh 
penimbunan bilirubin dalam jaringan tubuh sehingga kulit, mukosa, dan sklera berubah warna menjadi kuning yang sering disebut hiperbilirubinemia pada bayi. Masalah ini sering disebabkan oleh faktor maternal diantaranya inkompabilitas $\mathrm{ABO}$ dan $\mathrm{Rh}$, juga pemberian ASI dan ada juga faktor penyebab lain yaitu bayi kurang bulan, usia gestasi, BBLR, dan perinatal (infeksi, hipoglikemia serta jenis persalinan) (Sukadi, 2008).

Pemberian ASI secara dini pada neonatus dapat mengurangi terjadinya ikterus fisiologis. Menyusui dini atau permulaan menyusu dini adalah bayi mulai menyusu sendiri segera setelah lahir (Roesli, 2012). Manajemen menyusui optimal adalah tindakan pemberian ASI pada bayi yang memadai, meliputi: inisiasi menyusu dini pada satu jam pertama, manajemen menyusui (ASI) yang optimal setidaknya 8-12 kali per hari tanpa pemberian air atau makanan tambahan lain, menyusui dengan posisi yang benar sehingga dapat dipastikan transfer ASI secara efektif; mencegah kehilangan berat lahir kurang dari 8\% (Gartner, 2013).

Penelitian yang dilakukan (Hidayati, 2016) diketahui bahwa angka kejadian hiperbilirubinemia meningkat pada neonatus jenis kelamin laki-laki dibandingkan perempuan, meningkat pada kasus neonatus dengan preterm dibandingkan dengan neonatus aterm, dan pemberian ASI yang kurang dari 8 kali/hari (72\%) dibandingkan dengan frekuensi menyusui ASI yang lebih dari 8 kali/hari (27,9\%). Hal itu menunjukkan bahwa frekuensi menyusui ASI dapat mempengaruhi terjadinya hiperbilirubinemia termasuk juga lama menyusui ASI.

Pada penelitian (Dasnur \& Sari, 2018) menyatakan pemberian ASI sangat penting dilakukan mulai dari bayi baru dilahirkan, terutama pemberian ASI pertama yang sering disebut (colostrum). Pada penelitiannya juga menjelaskan frekuensi pemberian ASI menjadi salah satu faktor yang mempengaruhi ikterus pada bayi.

Studi pendahuluan yang penulis lakukan pada tanggal 10 Maret sampai dengan 10 April 2020 di Ruang Intensif RSIA Puri Bunda Denpasar, diketahui bahwa kasus bayi dengan hiperbilirubinemia termasuk urutan1 terbesar dan terbanyak dijumpai. Hiperbilirubinemia ini menduduki no 1 selanjutnya RDS (respiratory distress syndrome), BBLR (Bayi Berat Lahir Rendah), DHF (Dengue Hemoragi Fever) dan asfiksia. Dari hasil observasi terdapat 15 bayi hiperbilirubinemia fisiologis yang dirawat, $60 \%$ dengan derajat ikterik III dan $40 \%$ ada pada 
kategori derajat IV dengan total serum bilirubin berkisar anatara 12-20 mg\%/dL

Berdasarkan masalah yang ditemui pada latar belakang diatas maka penulis tertarik untuk meneliti Hubungan Pemberian ASI Dengan Kejadian Ikterus Bayi Hiperbilirubinemia di RSIA Puri Bunda Denpasar.

\section{METODE}

Penelitian ini sudah lolos uji etik dengan NO: 257/EA/KEPK-BUB-2020. Penelitian ini adalah Case control dimana penelitian ini merupakan suatu penelitian yang membandingkan kelompok kasus dengan kelompok kontrol untuk mengetahui proporsi kejadian berdasarkan riwayat dengan menggunakan pendekatan retrospective (Swarjana, 2015). Peneliti menggunakan data sekunder berupa data Rekam Medik RSIA Puri Bunda Denpasar tahun Januari-Juni 2020, dari data sekunder tersebut peneliti ingin mengetahui hubungan pemberian ASI terhadap kejadian Ikterus dan hiperbilirubinemia. Dalam penelitian ini, data bayi yang mengalami ikterus dan hiperbilirubinemia diidentifikasi pada saat ini kemudian dihubungkan dengan faktor risiko pemberian ASI yang mengalami ikterus dan hiperbilirubinemia.

Peneliti menggunakan data sekunder berupa data Rekam Medik RSIA Puri
Bunda Denpasar tahun Januari - Juni 2020, dari data sekunder tersebut peneliti ingin mengetahui hubungan pemberian ASI terhadap kejadian Ikterus dan hiperbilirubinemia. Dalam penelitian ini, data bayi yang mengalami ikterus dan hiperbilirubinemia diidentifikasi pada saat ini kemudian dihubungkan dengan faktor risiko pemberian ASI yang mengalami ikterus dan hiperbilirubinemia

Jumlah sampel penelitian ini sebanyak 86 berkas RM dengan kriteria inklusi 1) Rekam Medis lengkap dan 2) diambil dari data RM dari bulan Januari sampai dengan Juni tahun 2020 pada neonatus yang mengalami kejadian ikterus bayi hiperbilirubinemia yang dirawat di Ruang Intensif RSIA Puri Bunda Denpasar. Analisis statistik dengan uji korelasi Chi Square menggunakan taraf signifikasi $\alpha=0,05$, artinya jika uji statistik menunjukkan nilai $\mathrm{p} \leq 0,05$

\section{HASIL DAN PEMBAHASAN}

Penelitian ini dilaksanakan pada tanggal 13 Oktober sampai tanggal 13 November 2020. Hasil penelitian didapatkan data rekam medis pada kelompok kasus hanya 1 orang (100\%) yang tidak mengalami ikterus dengan pemberian ASI dan Susu Formula, terdapat 7 orang $(16,7 \%)$ bayi yang mengalami ikterus dengan pemberian 
ASI eksklusif Sedangkan bayi yang mengalami ikterus terbanyak pada pemberian ASI dan Susu Formula sebanyak 35 orang (83,3\%). Pada kelompok kontrol didapatkan hanya 1 data rekam medis (100\%) yang tidak mengalami ikterus, terdapat 7 orang $(16,7 \%)$ yg mengalami ikterus dengan pemberian ASI eksklusif dan bayi yang mengalami ikterus terbanyak pada pemberian ASI dan Susu Formula sebanyak 35 orang $(83,3 \%)$.

Tabel 1. Pemberian ASI Pada Ikterus Kasus

\begin{tabular}{lcccc}
\hline \multirow{2}{*}{ Karakteristik } & \multicolumn{4}{c}{ Ikterus Kasus } \\
\cline { 2 - 5 } & \multicolumn{2}{c}{ Ikterus (-) } & \multicolumn{3}{c}{ Ikterus (+) } \\
\cline { 2 - 5 } & $\boldsymbol{f}$ & $\boldsymbol{\%}$ & $\boldsymbol{f}$ & $\boldsymbol{\%}$ \\
\hline ASI & 0 & 0 & 7 & 16,7 \\
Eksklusif & & & & \\
\hline $\begin{array}{l}\text { ASI dan Susu } \\
\text { Formula }\end{array}$ & 1 & 100 & 35 & 83,3 \\
\hline
\end{tabular}

Data pemberian ASI pada Tabel 1 hanya 1 orang (100\%) yang tidak mengalami ikterus dengan pemberian ASI dan Susu Formula. Sedangkan bayi yang mengalami ikterus terbanyak pada pemberian ASI dan Susu Formula sebanyak 35 orang $(83,3 \%)$.

Tabel 2. Pemberian ASI Pada Ikterus Kontrol

\begin{tabular}{lcccc}
\hline & \multicolumn{4}{c}{ Ikterus Kontrol } \\
\cline { 2 - 5 } Karakteristik & Ikterus (-) & \multicolumn{1}{c}{ Ikterus (+) } \\
\cline { 2 - 5 } & $\boldsymbol{f}$ & $\boldsymbol{\%}$ & $\boldsymbol{f}$ & $\boldsymbol{\%}$ \\
\hline ASI & 0 & 0 & 7 & 16,7 \\
Eksklusif & & & & \\
\hline $\begin{array}{l}\text { ASI dan Susu } \\
\text { Formula }\end{array}$ & 1 & 100 & 35 & 83,3 \\
\hline
\end{tabular}

Data pemberian ASI pada Tabel 2 didapatkan hanya 1 data rekam medis
(100\%). Sedangkan bayi yang mengalami ikterus terbanyak pada pemberian ASI dan Susu Formula sebanyak 35 orang $(83,3 \%)$.

a. Kejadian ikterus pada bayi hiperbilirubineamia

Tabel 3. Pemberian ASI Pada Hiperbilirubin Kasus

\begin{tabular}{lcccc}
\hline \multirow{2}{*}{ Karakteristik } & \multicolumn{3}{l}{ Hiperbilirubin Kasus } \\
\cline { 2 - 5 } & $\begin{array}{c}\text { bilirubin } \\
\text { normal }\end{array}$ & \multicolumn{2}{c}{$\begin{array}{c}\text { bilirubin } \\
\text { meningkat }\end{array}$} \\
\cline { 2 - 5 } & $\boldsymbol{f}$ & $\boldsymbol{\%}$ & $\boldsymbol{f}$ & $\boldsymbol{\%}$ \\
\hline ASI Eksklusif & 0 & 0 & 7 & 16,7 \\
\hline ASI dan Susu & 1 & 100 & 35 & 83,3 \\
Formula & & & & \\
\hline
\end{tabular}

Tabel 3 menunjukkan dari 43 orang yang dijadikan sampel penelitian. ditemukan pada kelompok kasus menunjukkan pemberian ASI dan Susu Formula yang hanya 1 orang (100\%) yang tidak mengalami bilirubin normal. Sedangkan bayi yang mengalami bilirubin meningkat terbanyak pada pemberian ASI dan Susu Formula sebanyak 35 orang $(83,3 \%)$.

Tabel 4. Pemberian ASI Pada Hiperbilirubin Kontrol

\begin{tabular}{lcccc}
\hline \multirow{2}{*}{ Karakteristik } & \multicolumn{2}{c}{ Hiperbilirubin Kontrol } \\
\cline { 2 - 5 } & $\begin{array}{l}\text { Bilirubin } \\
\text { normal }\end{array}$ & \multicolumn{2}{c}{$\begin{array}{c}\text { Bilirubin } \\
\text { meningkat }\end{array}$} \\
\cline { 2 - 5 } & $\boldsymbol{f}$ & $\mathbf{\%}$ & $\boldsymbol{f}$ & $\mathbf{\%}$ \\
\hline ASI Eksklusif & 0 & 0 & 2 & 4,8 \\
\hline ASI dan Susu & 1 & 100 & 40 & 95,2 \\
Formula & & & & \\
\hline
\end{tabular}

Tabel 4 dari 43 orang yang analisis data menemukan pada kelompok kontrol pemberian ASI dan Susu Formula hanya 1 orang (100\%). Sedangkan bayi yang mengalami peningkatan bilirubin 
terbanyak pada pemberian ASI dan Susu

Formula sebanyak 40 orang $(95,2 \%)$

Berdasarkan tujuan penelitian menganalisis hubungan Pemberian ASI dengan Kejadian Ikterus pada bayi hiperbilirubinemia di RSIA Puri Bunda Denpasar dilakukan dengan melakukan analisis Chi Square variabel dependen (Ikterus) dan karakteristik data penelitian sebagai berikut:

Tabel 5. Distribusi Frekuensi Hubungan Pemberian ASI Dengan Kejadian Ikterus Pada Bayi Hiperbilirubinemia

\begin{tabular}{lccccccc}
\hline \multirow{2}{*}{\begin{tabular}{l} 
Pemberian \\
\multicolumn{1}{c}{ ASI }
\end{tabular}} & \multicolumn{4}{c}{ Kejadian Ikterus } & \multirow{2}{*}{ Total } & \multirow{2}{*}{$\boldsymbol{p}$} \\
\cline { 2 - 6 } & \multicolumn{2}{c}{ Kasus } & \multicolumn{2}{c}{ Kontrol } & & & value \\
\cline { 2 - 6 } & $\boldsymbol{f}$ & $\boldsymbol{\%}$ & $\boldsymbol{f}$ & $\boldsymbol{\%}$ & $\boldsymbol{f}$ & $\boldsymbol{\%}$ & \\
\hline ASI & 7 & 16,3 & 7 & 16,3 & 14 & 16,3 & \\
Eksklusif & & & & & & & \\
\hline ASI dan & 36 & 83,7 & 36 & 83,7 & 72 & 83,7 & 0,023 \\
Susu & & & & & & & \\
Formula & & & & & & & \\
\hline
\end{tabular}

Berdasarkan Tabel 5 hasil analisa hubungan antara pemberian ASI dengan kejadian ikterus pada bayi hiperbilirubinemia, bahwa pemberian asi eksklusif lebih sedikit terjadinya ikterus (16,3\% pada kelompok kasus dan kelompok kontrol) sedangkan kejadian ikterus lebih tinggi pada pemberian ASI dan Susu Formula baik pada kelompok kasus maupun kelompok kontrol. hasil uji statistik chi square diperoleh nilai $\mathrm{p}=$ 0,023 berarti terdapat hubungan yang signifikan antara pemberian ASI dengan kejadian ikterus pada bayi hiperbilirubinemia.

\section{Pembahasan}

Analisis data dilakukan terhadap variabel-variabel yang diteliti. Analisis data yang dilakukan yaitu analisis univariat, untuk memberikan gambaran mengenai jumlah dan persentase data rekam medis yang mengalami ikterus dan bilirubin baik pada kelompok kasus maupun kelompok kontrol, dari data rekam medis yang peneliti gunakan serta analisis bivariat untuk menguji pengaruh antara variabel pemberian ASI dengan kejadian ikterus bayi hiperbilirubinemia.

Dalam penelitian ini didapatkan sebanyak 43 orang pada kelompok kasus dan 43 orang pada kelompok kontrol pada bayi yang diberikan ASI yang mengalami kejadian ikterus bayi hiperbilirubinemia.

\section{Pemberian ASI di RSIA Puri Bunda Denpasar}

Hasil penelitian dari 86 data rekam medis pada kelompok kasus maupun kelompok kontrol didapatkan hanya 2 data rekam medis ( 2 orang) yang $100 \%$ tidak mengalami ikterus dengan pemberian ASI dan Susu Formula, terdapat 14 berkas rekam medis (14 orang) atau $16,7 \%$ bayi yang mengalami ikterus dengan pemberian ASI eksklusif Sedangkan bayi yang mengalami ikterus terbanyak pada pemberian ASI dan Susu Formula sebanyak 70 berkas rekam medis (70 orang) atau sekitar 83,3\%. 


\section{Kejadian ikterus pada bayi hiperbilirubinemia di RSIA Puri Bunda Denpasar}

Kejadian ikterus pada bayi hiperbilirubinemia pada kelompok kasus menunjukkan pemberian ASI dan Susu Formula yang hanya 1 data rekam medis (1 bayi) atau $100 \%$ yang tidak mengalami peningkatan bilirubin. Sedangkan bayi yang mengalami bilirubin meningkat terbanyak pada pemberian ASI dan Susu Formula sebanyak 35 berkas rekam medis (35 bayi) yaitu $83,3 \%$. Pada kelompok kontrol pemberian ASI dan Susu Formula hanya 1 data rekam medis (1 Bayi) yang 100\%). Sedangkan bayi yang mengalami peningkatan bilirubin terbanyak pada pemberian ASI dan Susu Formula sebanyak 35 berkas rekam medis (35 bayi) yaitu $83,3 \%$ dan 7 rekam medis (7 bayi) yaitu $16,7 \%$ tetap mengalami peningkatan bilirubin walaupun di berikan ASI eksklusif saja.

Ikterus neonatorum merupakan perubahan warna menjadi kuning yang terjadi pada neonatus atau bayi yang baru lahir. Perubahan warna ini dapat dilihat pada mata, rongga mulut, dan kulit. Ikterus neonatorum dapat bersifat fisiologis atau normal terjadi pada bayi dan patologis atau yang tidak normal pada bayi baru lahir serta dapat mengancam nyawa. Pada bayi-bayi prematur terjadi peningkatan angka kejadian ikterus neonatorum dibandingkan dengan bayi-bayi cukup bulan (Noorbaya, 2019). Warna kuning meliputi kulit wajah, kepala menunjukkan bahwa kadar bilirubin dalam serum adalah $5 \mathrm{mg} / \mathrm{dL}$, bila telah mencapai pertengahan abdomen adalah $15 \mathrm{mg} / \mathrm{dL}$ dan bila warna kuning telah mencapai telapak kaki maka kadarnya adalah $20 \mathrm{mg} / \mathrm{dL}$ (Widagdo, 2012).

Ikterus fisiologis merupakan bentuk yang paling sering terjadi pada bayi baru lahir. Jenis bilirubin yang menyebabkan pewarnaan kuning pada ikterus disebut bilirubin tidak terkonjugasi, merupakan jenis yang tidak mudah dibuang dari tubuh bayi. Hati bayi akan mengubah bilirubin ini menjadi bilirubin terkonjugasi yang lebih mudah dibuang oleh tubuh (Budi Artha, 2017). Breastfeeding jaundice, dapat terjadi pada bayi yang mendapat air susu ibu (ASI) eksklusif, terjadi akibat kekurangan ASI yang biasanya timbul pada hari kedua atau ketiga pada waktu ASI belum banyak dan biasanya tidak memerlukan pengobatan. Ikterus ASI (breastmilk jaundice), berhubungan dengan pemberian ASI dari seorang ibu tentu dan biasanya akan timbul pada bayi yang diberikan susu, tergantung pada kemampuan bayi tersebut mengubah bilirubin indirek. Ikterus pada bayi akan terjadi pada kasus ketidakcocokan golongan darah (inkompatibilitas $A B O$ ) dan rhesus 
(inkompatibilitas rhesus) ibu dan janin (Budi Artha, 2017). Dalam hepar terjadi mekanisme ambilan, sehingga bilirubin terkait oleh reseptor membrane sel hati dan masuk ke dalam sel hati. Segera setelah sel dalam hati, terjadi persenyawaan dengan ligandin (proteinY, protein-Z dan glutation hati lain yang membawa ke reticulum endoplasma hati, tempat terjadi konjugasi) (Jejeh, 2010).

Kesimpulan bahwa ikteruk neonatus merupakan perubahan warna kulit yang terjadi pada bayi baik yang memperoleh ASI eksklusif, maupun ASi eksklusif + Susu Formula dengan kadar bilirubin dalam darah mencapai lebih dari 10 mg/dl pada 24 jam pertama kehidupan, dan terjadi karena bilirubin tidak terkonjugasi oleh hepar, sehingga tidak dapat diekskresikan dari tubuh dan menumpuk pada darah, bila tidak ditangani dengan tepat dapat menimbulkan terjadinya kern ikterus yang merupakan kerusakan otak akibat perlekatan bilirubin indirek pada otak.

\section{Hubungan Pemberian ASI dengan Kejadian Ikterus pada bayi hiperbilirubinemia di RSIA Puri Bunda Denpasar}

Hasil uji bivariat hubungan pemberian ASI dengan kejadian Ikterus pada bayi hiperbilirubinemia di RSIA Puri Bunda Denpasar dilakukan dengan melakukan analisis Chi Square didapatkan hasil analisis bahwa pemberian ASI eksklusif lebih sedikit terjadinya ikterus $\quad(16,7 \%$ pada kelompok kasus dan kelompok kontrol) sedangkan kejadian ikterus lebih tinggi pada pemberian ASI dan susu formula baik pada kelompok kasus maupun kelompok kontrol. hasil uji statistik chi square diperoleh nilai $\mathrm{p}=0,023$ berarti terdapat hubungan yang signifikan antara pemberian ASI dengan kejadian ikterus pada bayi hiperbilirubinemia.

Bilirubin merupakan produk yang bersifat toksik dan harus dikeluarkan oleh tubuh. Sebagian besar hasil bilirubin berasal dari degredasi hemoglobin darah dan sebagian lagi berasal dari hem bebas atau dari proses eritropoesis yang tidak efektif. Pembentukan bilirubin tadi dimulai dengan proses oksidasi yang menghasilkan biliverdin serta beberapa zat lain (Jejeh, 2010). Gejala utama yang dapat dilihat pada bayi adalah perubahan warna menjadi kuning yang dapat dilihat pada mata, rongga mulut, dan kulit. Perubahan ini awalnya mudah tampak dari mata lalu apabila makin berat dapat menjalar hingga ke dada, perut, tangan, paha, hingga ke telapak kaki. Untuk mengatasi ikterus dan hiperbilirubin. Bayi yang diberikan ASI lebih mampu menghadapi efek penykit kuning. Jumlah bilirubin dalam darah bayi banyak berkurang seiring diberikan kolostrum yang dapat mengatasi kekuningan, asalkan bayi tersebut 
disusui sesering mungkin dan tidak diberikan pengganti ASI (Dasnur, 2018). Kolostrum dalam ASI adalah cairan pelindung yang kaya akan zat anti infeksi dan mengandung tinggi protein yang keluar hari pertama sampai hari ke4 atau ke-7 setelah melahirkan (Marni, 2012). Kolostrum memiliki kandungan vitamin yang larut dalam lemak, immunoglobulin Ig A, Ig $\mathrm{G}$ dan Ig $\mathrm{M}$ dibandingkan dengan ASI matur, namun memiliki total energi lebih rendah. Jumlah kolostrum masih terbatas karena masih dihambat oleh tingginya kadar estrogen (Marni, 2012). Penggunaan susu formula justru akan mengganggu perkembangan dan menyebabkan kerusakan saluran pencernaan (Dasnur, 2018).

Penelitian kohort yang dilakukan oleh Suryandari dan Agustina (2013) mendapatkan hasil, terdapat perbedaan kejadian ikterus fisiologis pada bayi baru lahir dengan pemberian kolostrum dini dan tidak diberi kolostrum secara dini dimana bayi baru lahir normal yang tidak diberi kolostrum secara dini 13,5 kali lebih besar mengalami ikterus fisiologis dibandingkan bayi yang diberikan kolostrum secara dini.

Penelitian yang dilakukan oleh Dasnur dan Sari (2018) dimana pemberian ASI $>8$ kali sehari dapat mengurangi bilirubin dalam darah dan dapat mengatasi kuning pada bayi, dengan desain penelitian Deskritif analitik dan pendekatan cross sectional study dengan menggunakan hasil uji chi square didapatkan hubungan Frekuensi pemberian ASI dengan kejadian ikterus fisiologis pada bayi.

Pada penelitian yang dilakukan Rana (2018) pemberian ASI sedini mungkin pada bayi untuk mendapatkan kolostrum sehingga memiliki kemampuan untuk mengeluarkan bilirubin yang tinggi pada saat bayi $\mathrm{BAB}$, desain penelitian yang digunakan yaitu observasional analitik dengan pendekatan kohort dan dianalisa dengan koefesien korelasi Sperman, uji statistik didapatkan nilai $p=0,004$ dengan kata lain ada hubungan waktu pemberian ASI dengan kejadian ikterus neonatorum.

Dengan demikian ASI dapat dikatakan dapat berhubungan menurunkan ikterus dan hiperbilirubin karena ASI memiliki kandungan Imuniglobulin dan kolostum yang berperan menurunkan kejadian hiperbilirubin dan ikterus pada bayi.

\section{KESIMPULAN DAN SARAN}

Berdasarkan hasil penelitian didapatkan hubungan yang signifikan pada pemberian ASI dengan kejadian ikterus bayi hiperbilirubin. 86 data rekam medis baik pada kelompok kasus maupun kontrol yang masing-masing kelompok terdapat 1 data rekam medis 
(100\%) yang tidak mengalami ikterus dan hiperbilirubin dengan pemberian ASI dan Susu Formula, sedangkan yang mengalami ikterus dan hiperbilirubin terbanyak pada pemberian ASI dan Susu Formula sebanyak 35 berkas rekam medis $(83,3 \%)$ dan 7 data rekam medis $(16,7 \%)$ tetap mengalami peningkatan pada pemberian ASI eksklusif. Hubungan pemberian ASI dengan kejadian ikterus pada bayi hiperbilirubinemia, yaitu pemberian ASI eksklusif lebih sedikit terjadinya ikterus dan hiperbilirubinemia (16,7\%) pada kelompok kasus dan kelompok kontrol, sedangkan kejadian ikterus dan hiperbilirubinemia lebih tinggi pada pemberian ASI dan susu formula $(83,3 \%)$ baik pada kelompok kasus maupun kelompok kontrol. hasil uji statistik chi square diperoleh nilai $\mathrm{p}=$ 0,023 berarti terdapat hubungan yang signifikan antara pemberian ASI dengan kejadian ikterus pada bayi hiperbilirubinemia.

\section{UCAPAN TERIMAKASIH}

Peneliti mengucapkan terimakasih kepada semua pihak yang yang terlibat dalam penelitian ini dan juga RSIA Puri Bunda Denpasar yang telah memberikan ijin serta dukungannya dalam melakukan penelitian

\section{DAFTAR PUSTAKA}

Badan Pusat Statistik. (2021). Survey Demografi dan Kesehatan tahun 2012.

Budi Artha, K. (2017). Faktor-Faktor yang Berhubungan dengan Pemberian ASI Ekslusif Oleh Ibu Menyusui yang Bekerja Sebagai Tenaga Kesehatan. Jurnal Ilmu Kesehatan 2, 159-174.

Dasnur, D., \& Sari, I. M. (2018). Hubungan frekuensi pemberian Asi Terhadap Kejadian Ikterus Fisiologis Pada Bayi Baru Lahir Di Semen Padang Hospital Tahun 2017. Jurnal Kesehatan.

Dinas Kesehatan. (2017). Profil Kesehatan Provinsi Bali 2017.

Gartner. (2013). Breastfeeding and Jaundice.

Hidayati, E. \& R. (2016). Hubungan Faktor Ibu dan Faktor bayi dengan kejadian Hiperbilirubinnemia Pada Bayi baru lahir (BBL) Di rumah Sakit. Jurnal Biomedik.

Jejeh. (2010). Asuhan Neonatus Bayi dan Anak Balita.

KemenkesRI. (2015). Profil Kesehatan Indonesia Tahun 2014. Jakarta: Kementrian Kesehatan RI.

KemenkesRI. (2017). Profil Kesehatan Indonesia Tahun 2015. Jakarta: Kementrian Kesehatan RI.

Marni, S., \& R. (2012). Asuhan Neonatus Bayi, Balita \& Anak Prasekolah.

Noorbaya, S. (2019). Panduan Belajar Asuhan Neonates, Bayi, Balita Dan Anak Prasekolah. Yogyakarta: Gosyen Publishing.

Rana, R. (2018). Waktu pemberian asi dan kejadian ikterus neonatorum. Jurnal Informasi Kesehatan Indonesia, 4(1), 43-52.

Roesli. (2012). Inisiasi Menyusui Dini Plus ASI Eksklusif.

Sukadi. (2008). Hiperbilirubinemia.

Suryandari, A. E.; \& Agustina, E. E. (2013). Perbedaan Waktu Pemberian Kolostrum Terhadap Kejadian Ikterus Fisiologis Pada Bayi Baru Lahir Di Rsu. Prof. Dr. Margono 
Soekarjo Tahun 2013. Jurnal

Involusi Kebidanan, 3(5), 1-12.

Swarjana. (2015). Metodologi Penelitian Kesehatan (Edisi Revisi).

WHO. (2019). Word Health Statistics 2019.

Widagdo. (2012). Tatalaksana Masalah Penyakit Anak dengan Ikterus. Jakarta: Sagung Seto. 